\title{
The Potential of Organisations' SWOT Diagnostic Assessment
}

\author{
Sandro Serpa \\ Department of Sociology, Faculty of Social and Human Sciences, University of the Azores; \\ Interdisciplinary Centre of Social Sciences - CICS.UAc/CICS.NOVA.UAc; \\ Interdisciplinary Centre for Childhood and Adolescence - NICA -UAc, Portugal \\ Carlos Miguel Ferreira \\ ISCTE -University Institute of Lisbon; \\ Interdisciplinary Centre of Social Sciences - CICS.NOVA; \\ Estoril Higher Institute for Tourism and Hotel Studies, Portugal \\ Maria José Sá \\ CIPES-Centre for Research in Higher Education Policies, Portugal
}

DOI: https://doi.org/10.36941/ajis-2020-0065

\begin{abstract}
The need to demonstrate high organisational efficiency has become central. In this context, organisational assessment becomes a critical element, although the specificities of each organisation are indisputable and have to be considered in their assessment. This paper aims to reflect on a specific type of diagnostic assessment - SWOT (Strengths, Weaknesses, Opportunities and Threats) - in its potential, implementation and limitations and, thus, to add to the analysis of organisations. For this purpose, the methodology used was based on the researchers' reflection and discussion of an empirical process of organisational diagnosis. The results of this reflection allow concluding that the SWOT diagnostic assessment needs to incorporate, in its systematic analysis, a prospective dimension to improve its efficiency in organisational strategy.
\end{abstract}

Keywords: organisation evaluation diagnostics, SWOT analysis, organisation strategy

"The perfect evaluation system that will clearly and objectively reveal how well your nonprofit organization is performing may never be found" (Murray, 2001, p. 39)

\section{Introduction}

Currently, there is increasing pressure for organisations to demonstrate their relevance and effectiveness to society, also taking into account the public funds they benefit from and the various stakeholders, which implies an assessment process (Bozzo, 200o; Filho, 2011; Carman, 2011; Murray, 2001; Ivanovi \& Anti, 2011; Mitchell \& Berlan, 2017; Henke, 1972; Solomon, 2018).

Any organisation must "respond effectively to the internal tensions and the pressures from the environment" (Pimentel, 2012, p. 159). Caetano (2004) identifies, in organisational dynamics, five levels of analysis that tend to be interdependent: individual, group, organisational, populations of 
organisations that share certain similar features, and communities of organisations as aggregates of populations of organisations. Furthermore, there are several proposals for the organisational assessment (Caetano, 2004).

The main goal of the assessment that organisational agents produce is to determine the strategies and actions to implement (Basten \& Haamann, 2018). One of the instruments rationally conceived and used to carry out this assessment is SWOT analysis.

The SWOT model emerged in the 196os, in a research work carried out by a team led by Robert Stewart and which included Albert S. Humphrey, Marion Dosher, Otis Benepe and Birger Lie. This research was funded by the companies included in the Fortune 500 index and aimed to identify the weaknesses inherent in business planning and, subsequently, to develop a new management model (Mateus, 2015).

This is an analytical technique used in strategic management that seeks, on the one hand, to ensure that the organisation is aligned with its environment and, on the other hand, to provide an answer about the organisation's strengths and weaknesses regarding present and future competitors (Porter, 1998; Santos, 2008; Thompson, Strickland, \& Gamble, 20o8; Hitt, Ireland, \& Hoskisson, 2009; Wheelen \& Hunger, 2012). Thus, SWOT analysis favours the organisation's internal and external level. The internal analysis seeks to list the organisation's available resources and, consequently, the difficulties or weaknesses that mark its evolution, that is, at the internal level, the analysis is carried out through the strengths and weaknesses, whereas the external analysis focuses on the description of the most important and relevant extrinsic factors and, consequently, the opportunities and threats that organisations face (Coelho, 2010; Koo, Koo, \& Luk, 2008).

The function of SWOT analysis is, therefore, to cross the organisation's external opportunities and threats with its strengths and weaknesses. This strategic assessment would be developed from the SWOT matrix. The aim is to relate the opportunities and threats of the external environment with the strengths and weaknesses of the organisation's internal environment. These four elements may be regarded as components of a diagnostic assessment and, consequently, as indicators of the organisation's situational reality (Chiavenato \& Sapiro, 2003).

Strengths or forces are controllable internal variables that provide favourable conditions regarding the environment. They are tangible or intangible elements, which may positively influence the organisation's performance. They are deemed to be enhancers and should be widely exploited by the organisation's leaders. Weaknesses are controllable internal variables that can generate negative conditions regarding the environment. They are negative aspects that must be improved by the different actors in an organisation.

Considering that the external environment entails factors that can influence positively or negatively the organisation of a present or future environment, opportunities may be defined as external uncontrolled variables that can provide favourable conditions, providing that the organisation wishes them and is capable of harnessing them. They are current or future conditions that should be widely explored by those responsible for the strategic management of an organisation. Threats or risks are uncontrolled external variables that can create unfavourable conditions, and that can negatively influence organisational performance, so they must inescapably be faced (Rezende, 2003; Boschmann \& Lima, 2014).

Given the above, this article seeks to answer the following research question: what is the potential and limitations of SWOT diagnostic assessment?

The article is structured as follows: next section details the methodology used to prepare this conceptual article. The following section offers a review of the literature deems most relevant for the discussion of the topic under analysis, specifically focusing on the organisational diagnosis and the SWOT analysis process. The article ends with the presentation of the main conclusions resulting from this analysis and discussion. 


\section{Methodology}

This article seeks, as mentioned above, to answer the following research question: What is the potential and limitations of SWOT diagnostic assessment in organisations?

This research favoured the document analysis technique, developed from different types of documentary sources. In a documentary study, documents may be viewed as «means of communication», produced for a given purpose and goal. Bearing in mind that documents are communication instruments and supports that express objective forms of experiences and knowledge related to a given sector of human practices, this means that the whole document is subject to contextualisation within a given social and cultural framework. In this framework marked by its complexity, the document relates to the framework of social relationships and takes on a given role in the game of social relationships, ascribing value to certain acts or shaping certain relationships (Lalanda-Gonçalves, 2014).

The type of favoured documentary sources includes handbooks, academic theses and articles produced in the disciplinary space of management and the field of social sciences, which, when expressing different stances and interests in the organisational, political and societal fields, were important in helping to understand the construction of the discursive space on SWOT analysis as an instrument rationally conceived and activated in the diagnostic assessment of organisations.

A meta-analysis of publications that directly focus on this topic currently was carried out. The collection was based on the consultation of the b-on database of the Foundation for Science and Technology (FCT) in Portugal, an electronic library that includes databases such as the Web of Knowledge, DOAJ (Directory of Open Access Journals) and SCIELO (Scientific Electronic Library Online), among others, as well as institutional repositories (Biblioteca do Conhecimento Online, online). A search was conducted between 1 and 1o October 2019, through the search for the word "SWOT", both in the abstract and in the title and terms of the topic. This online bibliographic search was complemented by the collection of complementary bibliographic material directly related to the topic under analysis.

In these documents, cognition policies are produced and expressed: language is used to build an «official» reality frequently around categorisations that produce the promotion or marginalisation of ideas, as well as the current concepts, which selectively define situations and shape readers' preferences, perceptions and cognitions. These documents may be regarded as places of symbolic struggles of the perception of the social world. These symbolic struggles can take on two different forms. The objective form shapes the possibility of acting through individual or collective representation actions, which aim to show and promote some realities. The subjective form models the possibility of acting in the attempt to change the categories of perception and appreciation of the social world, the cognitive and the evaluative structures: the categories of perception, the categorisation systems, that is, the words, the names that build the social reality as much as they express it (Carvalho, 2000; Ramos, 1981).

\section{Strategic Management and Diagnostic Assessment of Organisations}

Strategic management can be understood as a process that encompasses a set of decisions and actions that shape the performance of an organisation in the long term, and that are a sequential set of stages that shape it as a continuous, dynamic and interactive process, but also systematic and cyclical of analysis, choice and implementation (Mintzberg, 1994; Santos, 2008; Wheelen \& Hunger, 2012; Costa, 2018). In the strategic management process, although different authors put forward stages with distinct names, essentially three interdependent stages may be pointed out: strategic formulation; strategy implementation; and strategy assessment and control (António, 2015; David, 2009; Goldsmith, 1996; Pitts \& Lei, 2000; Thompson et al., 2013; Wheelen \& Hunger, 2012; Nobre, 2016).

The setting of long-term objectives, the appropriate policies and actions to attain them and the 
corresponding allocation of resources underlie the strategy, that is, the strategy comprises the definition of the objectives and the means (Chandler, 1962; Katz, 1970; Mintzberg, 1987; Ansoff \& McDonnel, 1990; Mintzberg \& Quinn, 1991; Porter, 1998, 2008; Santos, 2008; David, 2009; Wheelen \& Hunger, 2012; Costa, 2018). In the management of organisations, the processes for defining objectives, means and ways of attaining them, as well as their completion, cannot be seen as separate, but as a set of integrated and coherent processes.

The formulation of the strategy assumes the development of long-term plans, through the establishment of the organisation's mission and vision, the combination of external factors (characteristics and conditions of the environment) and internal conditions (dimension, material, human and organisational capacity), which shape each specific situation. The distinction between strategic vision and the mission statement is based on the assumption that the vision statement portrays the scope of the organisation's business in the future (where we are going). In turn, the mission statement describes the business and the purpose in the present (who we are, what we do) (Thompson, Strickland III, \& Gamble, 2008; Wheelen \& Hunger, 2012).

The formulation of the strategy originates from the combination of analyses of the organisation's external environment and internal competences (Freire, 2006). Through the organisational vision, the organisation's mission and strategic objectives are defined, as well as the governance style appropriate to the defined strategy. These components will determine the desired organisational development, entailing the definition of strategies for implementing the Strategy.

The formulation of the strategy presupposes the choice between strategic alternatives. Given that organisations do not have unlimited resources, it becomes necessary to develop and analyse alternative strategies at several levels, selecting the most advantageous to implement.

The implementation of the strategy consists of operationalising and executing the strategy, and which aims to assert the necessary conditions for the strategy to be available to the organisation's internal and external environment. The implementation and execution of the strategy are operationsoriented activities aimed at the performance of the dominant organisational activities, with the aim of supporting the strategy (Ferreira, 2011; Fairholm \& Card, 2009; Freire, 2006; Thompson Jr. et al., 2008).

To attain this goal, it is necessary to create a structure that supports the management of organisational resources and the implementation of the proposed objectives. The organisational structure, which is fundamental for the success of the strategy, indicates the way the organisation develops its activities and its processes, considering the critical success factors and the sources of competitive advantages. At the same time, it ensures the level of autonomy, creativity and flexibility appropriate to the execution of the defined strategy (Ferreira, 2011; Beaver, 2007; Freire, 2006).

The strategies are subject to change due to the volatility of both external and internal factors. The organisation monitors and assesses the execution of its objectives and the performance of the chosen strategy, as well as the process that accompanies the activities and results, to detect deviations in the outlined plans in advance and propose corrective actions (Thompson Jr. et al., 2008).

Thus, this stage of strategy control and assessment encompasses, in a first moment, the review of the external and internal factors underlying the current strategies, then the monitoring of the current performance and comparison with the desired performance, and, finally, the taking of corrective actions for solving problems. Controlling (through monitoring), assessing and making corrective adjustments is a way to decide the continuity or changes in the elements that underlie the production of the strategy, given that they provide the necessary parameters for corrective actions and the related adjustments to take when needed. Organisational controls steer the execution of the strategy, indicate how to compare the actual results with the expected results, and suggest corrective actions that should be taken when the difference is unacceptable. In this sense, formalised strategic planning should, hence, be associated with an information system that allows the monitoring of results and that they are aligned with the objectives (Armstrong, 1982; Santos, 2008; Hitt et al., 2009; Wheelen \& Hunger, 2012) Figure 1. 
Although control and assessment are the final stages of the strategic management process, it enables the identification of shortages in the strategy, both in terms of design and implementation (Hitt et al., 2009; Wheelen \& Hunger, 2012). Several authors state that many organisations have difficulties in implementing their strategy. The authors point out, as one of the causes, the fact that the strategic tools applied in the control and assessment do not follow the changes that are produced in the strategies (Kaplan \& Norton, 2001).

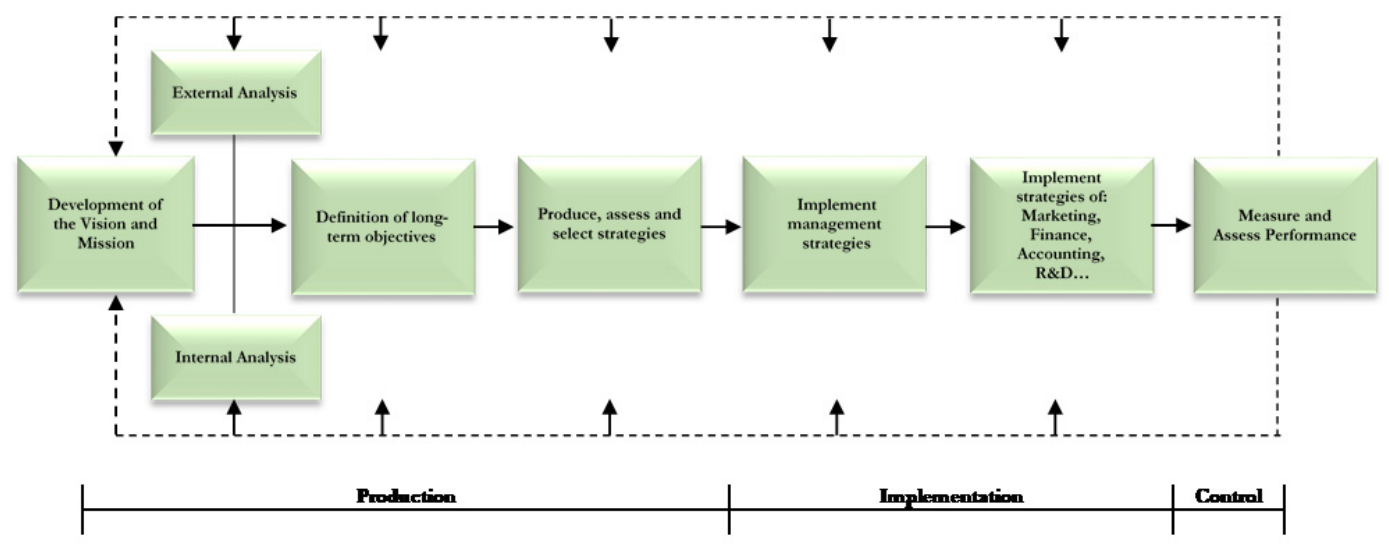

Figure 1: The strategic management process

Source: Adapted from David, 2009; Nobre, 2016.

Strategic tools may be regarded as a set of techniques that provide simplified information about a complex situation, assisting managers in the decision-making process and playing a critical role in the various stages of the strategic management process (Clark, 1997; Gunn \& Williams, 2007; Knott, 2006; Leskinen, Leskinen, Kurttilaa, \& Kajanus, 2006; Nobre, 2016). The most relevant strategic tools are the following: SWOT analysis; Value chain analysis; Scenario analysis; PEST analysis (Political, Economic, Social and Technological); Life cycle analysis; Portfolio analysis (e.g. BCG matrix or McKinsey matrix); Balanced scorecard; Michael Porter's five forces model; Risk analysis; Brainstorming; Analysis of resources and capabilities (e.g. VRIO analysis); and Benchmarking.

The legitimacy of the organisations' actions depends not only on their purpose but also on the participation of their members in management and production (Filho, 2011) and on demonstrating efficiency in fulfilling their mission (Villinger, 2009; Carman, 2011; Ivanović \& Antić, 2011; Mitchell \& Berlan, 2017). The organisational diagnostic assessment can also be a source of legitimacy for the organisation itself.

The organisational diagnosis is paramount in the identification of the problems, difficulties and constraints that negatively interfere in the organisation's effectiveness, as well as the possible factors that are at their base (Caetano, 2004), allowing to put forward possible solutions. According to Schalock et al. (2014), "Chief among these challenges are calls for increased effectiveness and efficiency based on outcomes evaluation, increased demands for services and supports commensurate with diminishing financial resources, and the need to focus on continuous quality improvement to increase an organization's effectiveness and efficiency" (p. 110).

For this assessment process to be successful, it is vital that it is continuous and participated by all institutional actors, with the active cooperation of stakeholders (Filho, 2011; Bozzo, 20oo; Caetano, 2004; Dubcová, Gajdová, \& Grančičová, 2016; Serpa, Ferreira, Santos, \& Teixeira, 2018) (Table 1). 
Table 1: Exemplary quality improvement strategies used for capacity building

\begin{tabular}{|c|c|}
\hline $\begin{array}{l}\text { Capacity building } \\
\text { focus }\end{array}$ & Exemplary quality improvement strategy \\
\hline $\begin{array}{l}\text { Services and } \\
\text { supports }\end{array}$ & $\begin{array}{l}\text { - Aligns services/supports to identified support needs } \\
\text { - Develops program options } \\
\text { - Horizontally aligns input, throughput, and output program components } \\
\text { - Vertically aligns an organization's input, throughput, and output components to the } \\
\text { corresponding individual-level input, throughput, and output components }\end{array}$ \\
\hline $\begin{array}{l}\text { Resource } \\
\text { development }\end{array}$ & $\begin{array}{l}\text { - Uses technology to enhance personal outcomes } \\
\text { - Enters into partnerships } \\
\text { - Utilizes high performance teams } \\
\text { - Monitors job satisfaction and develops job enrichment programs } \\
\text { - Analyzes overhead rate to increase efficiency }\end{array}$ \\
\hline $\begin{array}{l}\text { Research and } \\
\text { Evaluation }\end{array}$ & $\begin{array}{l}\text { - Measures personal and organizational outcomes } \\
\text { - Reports and analyses aggregated personal outcomes } \\
\text { - Compares unit costs across different locations and service delivery platforms } \\
\text { - Demonstrates the relationship between units of service/supports provided and the } \\
\text { clienteles' assessed support needs }\end{array}$ \\
\hline
\end{tabular}

Source: Schalock et al. (2014, p. 116).

Concerning the assessment of organisations, Pimentel (2012) argues that the professional/appraiser has to deal with two somewhat opposed requirements. On the one hand, he/she must ensure that his/her work has some continuity so that the intervention is properly planned, such as, for example, monitoring groups and meeting plans, among others. On the other hand, this professional should guarantee sufficient flexibility to maintain mobility and proximity to the phenomenon he/she is appraising. The author states that, in the absence of these conditions, "[...] the intervention risks disconnecting from the real, leading to a kind of illusion of change, intensified when the actors are confronted with the complexity of everyday life" (Pimentel, 2012, p. 160), which leads to some detachment.

\section{SWOT Analysis}

SWOT analysis has a long history and has been extensively studied (Phadermrod, Crowder, \& Wills, 2019; Sanchis-Palacio \& Melián-Navarro, 2011; Popescu \& Scarlat, 2015; Křupka, Kantorová, \& Haile, 2018; Bell \& Rochford, 2016). SWOT analysis is, as already indicated, the acronym for strengths, weaknesses, opportunities and threats (Křupka et al., 2018; Verboncu \& Condurache, 2016).

A rigorous SWOT analysis encompasses a set of steps, which Křupka et al. (2018) list as follows:

[...] 1st Specification for SWOT analysis; 2nd Assembling a team of specialists; 3rd Defining the internal and external environment; 4th Specifying factors in the individual quadrants of a SWOT matrix; 5 th Proof of evidence to individual factors; 6th Selection of the most important factors; 7 th Define key success/failures factors; 8th Selection of the SWOT strategy (Max-Max, Min-Max, ...); 9th Creating a company strategy and oth Creating a plan to implement the strategy. The SWOT analysis includes strategically important facts that are both realistic and valid in the range of about 6 months to 2 years. Within the SWOT analysis, it is also important to look at the interrelationships between strengths and weaknesses, opportunities and strengths (p. 136).

For Sanchis-Palacio and Melián-Navarro (2011), the ultimate goal of SWOT analysis is, more than simply providing a view of what the company is (the so-called diagnostic strategy). It is to provide grounded information on the most appropriate tools (the so-called strategic actions) that the organisation needs to deal with the challenges posed to it by the environment in which it operates. Hence, SWOT analysis and the resulting actions seek to mitigate the negative aspects that the 
diagnosis identified (the weaknesses and threats) and to enhance its positive aspects (strengths and opportunities).

However, several authors warn of the potential limitations of SWOT analysis, notably the integration of its elements (Bell \& Rochford, 2016; Vlados \& Chatzinikolaou, 2019), and/or its subjectivity, which may be controlled through strategies such as the triangulation of information, informants and analysts (Bell \& Rochford, 2016; Sanchis-Palacio \& Melián-Navarro, 2011; Popescu \& Scarlat, 2015; Křupka et al., 2018; Verboncu \& Condurache, 2016).

The SWOT matrix must be produced considering also the organisation's internal and external dynamics, as well as its future potential, minimising weaknesses and threats and enhancing strengths and opportunities. While this technique of organisational analysis is critical to the organisation, it has two limitations: on the one hand, it is a static analysis of the organisation and its status, that is, of how it is and where it is at a given moment, and, therefore, it does not offer a dynamic view of the path that the organisation should follow towards its evolution; on the other hand, the vision of the organisation that it allows obtaining is not absolute but relative, that is, it makes a comparison between the organisation and its competitors (Sanchis-Palacio \& Melián-Navarro, 2011).

In the sense that this dynamic is incorporated into SWOT analysis, we have, for example, the proposal of Popescu and Scarlat (2015), who suggest the SWOT analysis's enrichment with what they call Early Warning \& Opportunities System (EWOS), in the sense of also obtaining

[...] an outstanding capacity to "understand" and "benefit" in identifying opportunities and threats:

1. Business and Competitive Intelligence - give us the tools to understand what is happening in the business \& projects internal and external environment.

2. Early warning thinking - methodology to understand and visualize how various aspects of external and internal environment are interconnected each other.

3. Strategic thinking in decision process - based on the results and inputs provided by early warning and opportunity system and scenario analysis (p. 468).

Nazarko et al. (2017) propose an extended SWOT analysis - "SWOT Plus", inspired by the works of Sztando $(2006,2011,2016)$ on the four groups of classical SWOT analysis. This proposal adds several dimensions to the more traditional SWOT analysis discussed earlier (Figure 2).

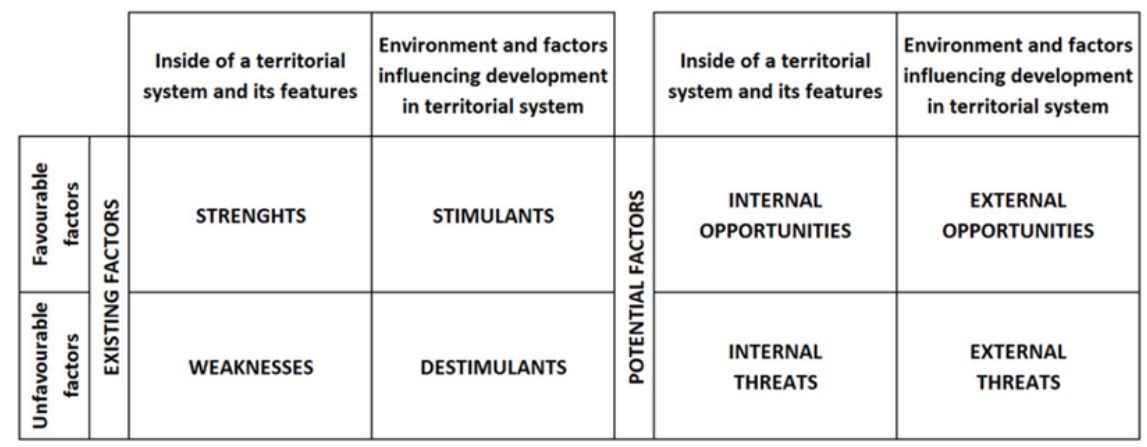

Figure 2: Diagram of SWOT Plus analysis

Source: Brol \& Sztando (2002), in Nazarko et al. (2017, p. 484).

The eight dimensions proposed by Nazarko et al. (2017) are as follows:

Strengths - most importantly, existing at the time of analysis, the properties of the system: active or inactive but it is possible to be activate; Weaknesses - most importantly, existing at the time of analysis, system properties, which are brakes or barriers to its development; Internal opportunities - opportunities with great potential, distinctive tested system, stemming from its internal structure; 
Internal threats - most importantly, the existing (but for now inactive) properties of analyzed system, which are the brakes of its development internal-system situations with high probability of losing the asset extension; Stimulants - active external factors contributing to the development of the system; Counter stimuli - active external factors that are barriers or brakes of system development; External opportunities - current the most important and potential, positive external factors; External threats most negative external factors, the occurrence of which in the projection horizon is highly likely (p. 484).

The authors add that, in the definition of the eight proposed dimensions, they took into account a set of criteria that have to do with (i) the existence of a factor existing at the time of the analysis or a potential one; (ii) the origin of this factor, with a detailed description of the organisation's internal and external environment and which can influence its development; and (iii) the nature of the (favourable or unfavourable) impact of that fact (Nazarko et al., 2017). Additionally, in the comprehensive analysis that the authors propose (SWOT Plus), the following factors should be included: (i) factors existing at the time the analysis is carried out and that influence the organisation; (ii) potential factors, which may have a positive or negative influence on the organisation in future terms; (iii) factors that are internal to the organisation, which characterise its activity and resources; (iv) factors that are external to the organisation, that is, environmental factors with influence on the organisation's functioning; (v) factors that are favourable or positive to the functioning of the organisation, which may be of an internal or external nature; and (vi) factors that are unfavourable or negative to the functioning of the organisation, which may also be of an internal or external nature (Nazarko et al., 2017).

Rahimiatani, Zare and Yazdani (2018), in their approach to the topic of agility and speed that currently characterise society, systems and organisations, argue that

Agility in modern era is one of the most important components of organizational superiority towards each other and achieving goals successfully. The speed of doing things and reacting appropriately to the changes are considered as the key factors of success in the present century [...]. Agile organizations think beyond adaptation to change and tend to use potential opportunities in a turbulent environment (pp. 140 and 141).

Rahimiatani et al. (2018) conclude that there is a set of factors influencing organisational agility at the meta-organisation's level, which are depicted in Table 2.

Table 2: The meta-organisational factors affecting organisational agility

\begin{tabular}{|c|c|c|}
\hline General class & Issues & Conceptual codes \\
\hline \multirow{4}{*}{$\begin{array}{l}\text { Meta- } \\
\text { Organizational } \\
\text { factors }\end{array}$} & Political attitude & $\begin{array}{l}\text { People's lack of trust in the government - Change in people's view in } \\
\text { recent years - Negative reaction to government decisions - No } \\
\text { participation in government affairs - Disregard for Bayt al-mal } \\
\text { consumption and loss of resources in unnecessary sectors. }\end{array}$ \\
\hline & Rules & $\begin{array}{l}\text { The lack of clarity of some regulations - Failure of rules to comply } \\
\text { with requirements - Some outdated rules - Overlap and interference } \\
\text { of some rules with each other. }\end{array}$ \\
\hline & $\begin{array}{l}\text { Inter- } \\
\text { organizational } \\
\text { relationships }\end{array}$ & $\begin{array}{l}\text { The lack of cooperation of some organizations - Prolongation of the } \\
\text { process of cooperation with organizations - Not justification of some } \\
\text { organs with issues and regulations - Individual look at issues in some } \\
\text { organizations - The absence of responsibility in organizations } \\
\text { towards each other - Unawareness of different organizations to the } \\
\text { goals of each other. }\end{array}$ \\
\hline & Media & $\begin{array}{l}\text { Government media coverage in Iran - The huge audience of the } \\
\text { media, especially the television - The great influence of the media on } \\
\text { the people - The high level of government control over the media - } \\
\text { The need to inform the people through radio and television - The } \\
\text { profound and well-known influence of the media on advertisements } \\
\text { and the disseminating a particular attitude. }\end{array}$ \\
\hline
\end{tabular}


Source: Rahimiatani et al. (2018, pp. 150-151).

In organisations' SWOT analysis, there are relevant issues to take into account. Among them, and adapting Bozzo (200o), the following are emphasised: (i) the need to analyse the various capacities, competences and resources existing in organisations; (ii) the importance of training employees to assist and be aligned with the analysis and assessment processes; (iii) the balance between the benefits of bottom-up and top-down approaches for the analysis and assessment; (iv) the difficulty in understanding methodologically complex assessments, as well as the data collected through them; (v) the lack of applicability of some assessment resources and tools; (vi) the lack of sensitivity of some approaches to the specificities of organisations, programs and activities; and (vii), finally, the use of the results of the assessments carried out (Bozzo, 200o).

\section{Conclusion}

This article advocates that SWOT analysis, if adequately carried out, has the potential to assist in the decision-making processes for profit or non-profit organisations (Mitchell \& Berlan, 2017). According to Blanco-Ariza, Messino-Soza, Vázquez-García, \& Melamed-Varela (2019),

This type of management in organizations is an opportunity to study and analyze each one of the particularities that it handles and contribute to the re-dimensioning of the social role inherent in organizations independent of their economic purposes. In this way, research has made it possible to identify how social innovation is a factor in the generation of value and social capital for this type of organization, identifying its nature and relationship with the social world and reinventing the ways of generating an impact upon society and the world (p. 11).

Still, and as Verboncu and Condurache (2016) alert, each organisation must take into account that recommendations (a) should not be mistaken with decisions; (b) highlight some areas in which management bodies must intervene; (c) should focus on the causes and not the effects, to be capable of fighting the former and, thus, minimise the latter; and (d) are starting points and bases for management approaches and strategic options or resources for the organisation.

One of the main frailties pointed out to SWOT analysis is the fact that it has little prospective potential, being able to generate and raise interesting questions based on the description of weaknesses and opportunities that are often not the target of theoretical and methodologically oriented reflection, thus limiting the ability to guide managers in the strategies and actions to implement. Criticisms focus on the fact that SWOT is based on subjective intuitions, is not systematic, does not favour quantitative methodologies and has no predictive potential (Agarwal, Grassl, \& Pahl, 2012). The uncritical use of strategic tools, as well as their instrumental, functional and theoretical simplicity, express a conception of the organisation as a space marked by the pinnacle of technical and instrumental rationality without favouring the particularity of the contexts and without questioning the instrumental validity of these tools with complex social phenomena (Rodrigues, 2011; Chanlat, 200o). Emphasis is placed on a conception of management as a neutral and rational technological instrument of control that seeks to attain collective, pre-established objectives, which are not attainable without its implementation (Reed, 1989). 


\section{Acknowledgement}

Funding: University of Azores, Interdisciplinary Centre of Social Sciences CICS.UAc/CICS.NOVA.UAc, UID/SOC/04647/2020, with the financial support of FCT/MEC through national funds and when applicable co-financed by FEDER under the PT2020 Partnership Agreement.

\section{References}

Agarwal, R., Grassl, W., \& Pahl, J. (2012). Meta-SWOT: Introducing a new strategic planning tool. Journal of Business Strategy, 33(2), 12-21. https://doi.org/10.1108/02756661211206708

Ansoff, I., \& Mcdonnell, E. (1990). Implanting strategic management. New Jersey: Prentice-Hall.

António, N. (2015). Estratégia organizacional: Do posicionamento ao movimento [Organisational strategy: From positioning to movement]. Lisbon: Edições Sílabo.

Armstrong, J. (1982). The value of formal planning for strategic decisions: Review of empirical research. Strategic Management Journal, 3(3), 197-211. https://doi.org/10.1002/smj.4250030303

Basten, D., \& Haamann, T. (2018). Approaches for organizational learning: A literature review. SAGE Open, 8(3). https://doi.org/10.1177/2158244018794224

Beaver, G. (2007). The strategy payoff for smaller enterprises. Journal of Business Strategy, 28(1), 11-17. https://doi.org/10.1108/02756660710723161

Bell, G. G., \& Rochford, L. (2016). Rediscovering SWOT's integrative nature: A new understanding of an old framework. The International Journal of Management Education, 14(3), 310-326. https://doi.org/10.1016/j.ijme.2016.06.0o3

Biblioteca do Conhecimento Online (online). What is b-on? https://www.b-on.pt/en/what-is-b-on/

Blanco-Ariza, A. B., Messino-Soza, A., Vázquez-García, A. W., \& Melamed-Varela, E. (2019). Social innovation in the non-profit organization framework: A review. Social Sciences, 8(8), 236. https://doi.org/10.339o/socsci8o80236

Boschmann, M., \& Lima, S. (2014). A análise SWOT como ferramenta para o planejamento estratégico governamental na área da saúde [SWOT analysis as a tool for government strategic planning in the health area]. Santa Maria: Universidade Federal de Santa Maria.

Bozzo, S. L. (2000). Evaluation resources for nonprofit organizations. Nonprofit Management and Leadership, 10(4), 463-472. https://doi.org/10.1002/nml.10409

Caetano, A. (2004). Mudança e intervenção organizacional [Organisational change and intervention]. In J. M. Ferreira, J. Neves, \& A. Caetano (Coords.), Manual de psicossociologia das organizações [Handbook of psychosociology of organisations] (pp. 531-565). Lisboa: McGraw-Hill.

Carman, J. G. (2011). Understanding evaluation in nonprofit organizations. Public Performance E Management Review, 34(3), 350-377. https://doi.org/10.2753/pmr1530-9576340302

Chandler, A. (1962). Strategy and structure. Cambridge, MA: MIT Press.

Chanlat, J. (2000). Ciências sociais e management [Social sciences and management]. São Paulo: Atlas.

Carvalho, L. (2000). Nós através da escrita: Revistas, especialistas e conhecimento pedagógico (1920-1936) [Us through writing: Magazines, experts and pedagogical knowledge (1920-1936)]. Lisboa: Educa.

Chiavenato, I., \& Sapiro, A. (2003). Planejamento estratégico: Fundamentos e aplicações [Strategic planning: Fundamentals and applications]. Rio de Janeiro: Elsevier.

Clark, D. N. (1997). Strategic management tool usage: A comparative study. Strategic Change, 6(7), 417-427. https://doi.org/10.1002/(SICI)1099-1697(199711)6:7<417::AID-JSC281>3.0.CO;2-9

Coelho, C. (2010). Projecto de um plano de marketing para o serviço para a educação contínua da FPCEUP [Project of a marketing plan for the service for continuing education of FPCEUP]. Porto: Faculty of Economics of the University of Porto.

Costa, A. (2018). Desenvolvimento de um modelo multimetodológico tridimensional de avaliação de desempenho organizacional: Competitividade, gestão estratégica e produtividade [Development of a three-dimensional multi-methodological model for evaluating organisational performance: Competitiveness, strategic management and productivity]. Doctoral dissertation. Évora: University of Évora.

David, F. (2009). Strategic management concepts and cases (12 ${ }^{\text {th }}$ ed.). Upper Saddle River: Pearson.

Dubcová, G., Gajdová, D., \& Grančičová, K. (2016). Evaluation of the functioning system of the social and solidarity economy in Slovakia. Procedia - Social and Behavioral Sciences, 230, 254-263. https://doi.org/10.1016/j.sbspro.2016.09.033 
Fairholm, M., \& Card, M. (2009). Perspectives of strategic thinking: From controlling chaos to embracing it. Journal of Management E Organization, 15(1), 17-30. https://doi.org/10.1017/S1833367200002856

Ferreira, A. (2011). Gestão estratégica e gestão do conhecimento na transferência do conhecimento, nas instituições de ensino superior público militar [Strategic management and knowledge management in knowledge transfer, in military public higher education institutions]. Doctoral dissertation. Covilhã: University of Beira Interior.

Filho, P. R. A. C. (2011). As especificidades do processo de avaliação das organizações de economia social [The specificities of the evaluation process of social economy organizations]. Revista Alcance - Eletrônica, 18, 414430.

Freire, A. (2006). Estratégia: Sucesso em Portugal [Strategy: Success in Portugal]. Lisboa: Editorial Verbo.

Goldsmith, A. A. (1996). Strategic thinking in international development: Using management tools to see the big picture. World Development, 24(9), 1431-1439. https://doi.org/10.1016/o305-750X(96)ooo54-X

Gunn, R., \& Williams, W. (2007). Strategic tools: An empirical investigation into strategy in practice in the UK. Strategic Change, 16(5), 201-216. https://doi.org/10.1002/jsc.799

Henke, E. O. (1972). Performance evaluation for not-for-profit organizations. The Journal of Accountancy, June, 5155 .

Hitt, M., Ireland, R., \& Hoskisson, R. (2009). Strategic management: Competitiveness and globalization (concepts and cases) ( $8^{\text {th }}$ ed.). Mason: South-Western Cengage Learning.

Ivanović, M., \& Antić, Z. (2011). Evaluation of results of nonprofit organizations. Management, 61, 99-105.

Kaplan, R., \& Norton, D. (2001). The strategy focused organization: How balanced scorecard companies thrive in the new business environment. Boston: Harvard School.

Katz, R. (1970). Cases and concepts in corporate strategy. New Jersey: Prentice-Hall Inc.

Knott, P. (2006). A typology of strategy tool applications. Management Decision, 44(8), $1090-1105$. https://doi.org/10.1108/00251740610690630

Koo, L. C., Koo, H., \& Luk, L. (20o8). A pragmatic and holistic approach to strategic formulation through adopting balanced scorecard, SWOT analysis and blue ocean strategy - A case study manufacturer in China. International Journal of Managerial and Financial Accounting, 1(2), 127-146. https://doi.org/10.1504/IJMFA.2008.021238

Křupka, J., Kantorová, K., \& Haile, M. (2018). SWOT analysis evaluations on the basis of uncertainty - Case study. In Scientific Papers of the University of Pardubice. Series D (pp. 135-146). Pardubice: University of Pardubice, Faculty of Economics and Administration.

Lalanda-Gonçalves, R. (2014). O documento nas ciências sociais: Construção e contextos sociais [The document in social sciences: Construction and social contexts]. In As transformações do documento no espaço-tempo do conhecimento [The transformations of the document in the space-time of knowledge]. III International Conference of the MUSSI Network, Bahia, Brazil, November 10-12.

Leskinen, L. A., Leskinen, P., Kurttilaa, M., \& Kajanus, M. (2006). Adapting modern strategic decision support tools in the participatory strategy process - A case study of a forest research station. Forest Policy and Economics, 8(3), 267-278. https://doi.org/10.1016/j.forpol.2004.06.007

Mateus, P. (2015). SWOT - A origem histórica e os conselhos do autor original [SWOT - The historical origin and advice of the original author]. Available at https://www.linkedin.com/pulse/swot-origem-hist $\% \mathrm{C}_{3} \% \mathrm{~B}_{3}$ ricae-os-conselhos-do-autor-original-pedro-mateus/

Mintzberg, H. (1987). The strategy concept I: Five P’s for strategy”. California Management Review, $30(1)$, 11-24. https://doi.org/10.2307/41165263

Mintzberg, H. (1994). The fall and rise of strategic planning. Harvard Business Review, 72(1), $107-114$.

Mintzberg, H., \& Quinn, J. (1991). The strategy process: Concepts, contexts and cases (2 ${ }^{\text {nd }}$ ed.). Englewood Cliffs: Prentice-Hall International.

Mitchell, G. E., \& Berlan, D. (2017). Evaluation in nonprofit organizations: An empirical analysis. Public Performance E Management Review, 41(2), 415-437. https://doi.org/10.1080/15309576.2017.1400985

Murray, V. (2001). The state of evaluation tools and systems for nonprofit organizations. New Directions for Philanthropic Fundraising, 31, 39-50. https://doi.org/10.1002/pf.3103.

Nazarko, J., Ejdys, J., Halicka, K., Magruk, A., Nazarko, L., \& Skorek, A. (2017). Application of enhanced SWOT analysis in the future-oriented public management of technology. Procedia Engineering, 182, 482-490. https://doi.org/10.1016/j.proeng.2017.03.140

Nobre, D. (2016). Ferramentas estratégicas em uso: Uma investigação prática às empresas em Portugal [Strategic tools in use: A practical research of companies in Portugal]. Master's dissertation. Lisbon: ISCTE.

Pitts, R., \& Lei, D. (200o). Strategic management: Building and sustaining competitive advantage ( ${ }^{\text {nd }}$ ed.). Ohio: South-Western College Publishing. 
Pimentel, D. (2012). Sociologia da empresa e das organizações. Uma breve introdução a problemas e perspectivas [Sociology of the company and organisations. A brief introduction to problems and perspectives]. Lisboa: Escolar Editora.

Phadermrod, B., Crowder, R. M., \& Wills, G. B. (2019). Importance-performance analysis based SWOT analysis. International Journal of Information Management, $194-203$. http://dx.doi.org/10.1016/j.ijinfomgt.2016.03.009

Popescu, F., \& Scarlat, C. (2015). Limits of SWOT analysis and their impact on decisions in early warning systems. SEA - Practical Application of Science, 3(1), 467-472.

Porter, M. (1998). Competitive strategy - Techniques for analyzing industries and competitors. New York: The Free Press.

Porter, M. E. (2008). The five competitive forces that shape strategy. Harvard Business Review, 86(1), 78-93.

Rahimiatani, A., Zare, H., \& Yazdani, H. (2018). Increasing organizational agility based on effective metaorganizational parameters. Postmodern Openings, 9(4), 140-156. https://doi.org/10.18662/po/49

Ramos, A. (1981). The new science of organizations. Toronto: University of Toronto Press.

Reed, M. (1989). The sociology of management. London: Harvester Wheatsheaf.

Rezende, D. (2012). Planejamento estratégico público ou privado: Guia para projetos em organizações de governo ou de negócios [Public or private strategic planning: Guide to projects in government or business organisations]. São Paulo: Atlas.

Rodrigues, R. (2011). A empresarialização da sociedade sob a influência da racionalidade da gestão [The entrepreneurialisation of society under the influence of management rationality]. Sociologia. Revista da Faculdade de Letras da Universidade do Porto, XXI, 233-255.

Sanchis-Palacio, J. R., \& Melián-Navarro, A. (2011). Strategic diagnosis of Spanish farming cooperative credit sections: A SWOT analysis. Annals of Public and Cooperative Economics, 82(2), $167-186$. https://doi.org/10.1111/j.1467-8292.2011.00435.X

Santos, A. (2008). Gestão estratégica. Conceitos, modelos e instrumentos [Strategic management. Concepts, models and instruments]. Lisboa: Escolar Editora.

Schalock, R. L., Lee, T., Verdugo, M., Swart, K., Claes, C., van Loon, J., \& Lee, C.-S. (2014). An evidence-based approach to organization evaluation and change in human service organizations evaluation and program planning. Evaluation and Program Planning, 45, 110-118. https://doi.org/10.1016/j.evalprogplan.2014.03.012

Serpa, S., Ferreira, C. M., Santos, A. I., \& Teixeira, R. (2018). Participatory action research in higher education training. International Journal of Social Science Studies, 6(6), 1. https://doi.org/10.11114/ijsss.v6i6.3286

Solomon, J. (2018). Monitoring and evaluation: Key steps for long-term services and supports organizations. Generations - Journal of the American Society on Aging, 42(1), 50-55.

Thompson Jr., A., Strickland III, A., \& Gamble, J. (2008). Administração estratégica [Strategic administration]. São Paulo: McGraw-Hill.

Thompson, A. A., Strickland III, A. J., Gamble, J. E., Peteraf, M. A., Janes, A., \& Sutton, C. (2013). Crafting and executing strategy: The quest for competitive advantage (European Ed.). Berkshire: McGraw Hill.

Thompson, A., Strickland, A., \& Gamble, J. (2008). Crafting and executing strategy: Concepts and cases (16 ${ }^{\text {th }}$ ed.). Boston: McGraw-Hill.

Verboncu, I., \& Condurache, A. (2016). Diagnostics vs. SWOT analysis. Review of International Comparative Management, 17(2), 114-122. Available at http://rmci.ase.ro/no17vol2/o3.pdf

Villinger, N. D. (2009). Analyzing non-profit organizations: Managerial frameworks and evaluation. The Journal of Global Business Issues, 3(1), 61-65.

Vlados, C., \& Chatzinikolaou, D. (2019). Towards a restructuration of the conventional SWOT analysis. Business and Management Studies, 5(2), 76. https://doi.org/10.11114/bms.v5i2.4233

Wheelen, T., \& Hunger, J. (2012). Strategic management and business policy: Toward global sustainability (13 ${ }^{\text {th }}$ ed.). New Jersey: Pearson Education. 